This article was downloaded by: [Universitetsbiblioteket i Bergen]

On: 26 J une 2013, At: 23:56

Publisher: Routledge

Informa Ltd Registered in England and Wales Registered Number: 1072954 Registered

office: Mortimer House, 37-41 Mortimer Street, London W1T 3J H, UK

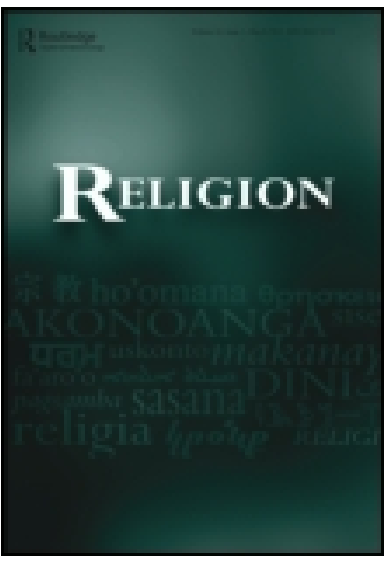

\title{
Religion
}

Publication details, including instructions for authors and subscription information:

http:// www. tandfonline.com/loi/ rrel20

\section{Textbooks in review: Introductions to the psychology of religion}

Michael Stausberg ${ }^{a}$

a Department of Archaeology, History, Cultural Studies and Religion, University of Bergen, Postboks 7850, 5020, Bergen, Norway

Published online: 05 Nov 2012.

To cite this article: Michael Stausberg (2013): Textbooks in review: Introductions to the psychology of religion, Religion, 43:2, 135-150

To link to this article: http:// dx.doi.org/ 10.1080/0048721X.2012.733619

\section{PLEASE SCROLL DOWN FOR ARTICLE}

Full terms and conditions of use: http://www.tandfonline.com/page/terms-andconditions

This article may be used for research, teaching, and private study purposes. Any substantial or systematic reproduction, redistribution, reselling, loan, sub-licensing, systematic supply, or distribution in any form to anyone is expressly forbidden.

The publisher does not give any warranty express or implied or make any representation that the contents will be complete or accurate or up to date. The accuracy of any instructions, formulae, and drug doses should be independently verified with primary sources. The publisher shall not be liable for any loss, actions, claims, proceedings, demand, or costs or damages whatsoever or howsoever caused arising directly or indirectly in connection with or arising out of the use of this material. 


\title{
Textbooks in review: Introductions to the psychology of religion
}

\author{
Michael Stausberg* \\ Department of Archaeology, History, Cultural Studies and Religion, University of Bergen, \\ Postboks 7850, 5020 Bergen, Norway
}

\begin{abstract}
The psychology of religion is generally acknowledged as a branch in the study of religion $\backslash \mathrm{s}$. This essay reviews current psychology of religion textbooks in English, German, Italian, and Swedish from a religious studies perspective (as distinct from a psychology perspective), in particular in terms of their fit with religious studies programs. It turns out that there are few books currently available that are suitable for adoption in religious studies courses.
\end{abstract}

KEY WORDS psychology of religion; textbooks

\section{The psychology of religion and the study of religionls}

The psychology of religion is one of the oldest branches - if not 'sub-disciplines' - in the study of religion $\backslash \mathrm{s} .{ }^{1}$ The psychology of religion is generally acknowledged as a (legitimate, natural, or even necessary) part of that package known as 'religious studies' or 'the study of religion $\backslash s^{\prime}$; accordingly, one finds chapters on the psychology of religion in several companion or handbook volumes serving as field guides to the study of religion \s. (For a comprehensive review see Engler 2008; chapters on the psychology of religion include Connolly 1999; Merkur 2005; Main 2006; Valle 2007; the subject is not included in Antes, Geertz and Warne 2004 and Orsi 2011). In the formative period of the field, psychological approaches were regarded as complementary to historical, philological, and phenomenological lines of inquiry. Similarly, in the formative period of the establishment of empirical psychology as an academic discipline in Europe and the U.S. late in the 19th century, religion was an occasional topic (Wulff 2010: 732). However, several developments in recent decades have led to the loss of reputation of psychology of religion among scholars of religion. Since experience and related themes like mysticism toppled from their pedestals as the main keys to understanding religion in the study of religion $\backslash \mathrm{s}$ and because religion has increasingly been conceived as public communication or discourse, psychological approaches were relegated to the backseats. ${ }^{2}$ Many academic psychologists, on the other hand, seem to regard

\footnotetext{
*Email: Michael.Stausberg@ahkr.uib.no

${ }^{1}$ See Engler and Stausberg (2011) on the disciplinary status of the study of religion $\backslash \mathrm{s}$.

${ }^{2}$ More recently, the rise of the so-called cognitive (or/and evolutionary) science of religion has heavily drawn on cognitive and evolutionary psychology (for the latter see Kirkpatrick 2011). The heavy reliance on psychology (even if not of the mainstream kind) may also have contributed towards the sense of
} 
religion with a high dose of suspicion; alternatively, there are pro-religious or even religious agendas, both of which most contemporary scholars of religion $\backslash \mathrm{s}$ tend to be critical of (Wulff 2010: 734). Moreover, the emphasis on empirical methods, often of the quantitative kind, as well as the professionalization and differentiation of psychology as a major academic discipline have removed findings in the psychology of religion from the immediate grasp and intellectual horizon of most scholars of religion \s. Furthermore, the practical dimensions of psychology of religion, namely counseling, diagnostics, and therapy, have no counterpart in the study of religion $\backslash$; r research questions such as pathogenic and salutiferous forms of religion or the benefits and costs of religiosity raise suspicions in a discipline that desperately seeks to avoid 'normative' issues and value judgments. Last but not least, there is the problem of mutual ignorance. When scholars of religion $\backslash \mathrm{s}$ think of psychological approaches, the names of Freud and Jung spring to mind, but their contributions are not what counts as psychology of religion among the vast majority of mainstream psychologists. Given the rather different research methodologies and questions used by mainstream scholars in both disciplines, scholars of religion $\backslash \mathrm{s}$ are not well prepared to appreciate and evaluate current work in the psychology of religion. (In comparison, work in the anthropology of religion looks more familiar in terms of methods, theories, research problems, and conceptual apparatus.)

As a result, there is at present no real meeting ground between the psychology of religion and the study of religion $\backslash s$ (the chapters mentioned above notwithstanding). Hardly any articles belonging to the psychology of religion are published in the main international journals (but see Belzen 2005); new books published within the psychology of religion are rarely if ever reviewed in our journals, the presence of psychological themes at the latest IAHR world congress (Toronto 2010) was minimal, and while the AAR has anthropology and sociology of religion groups, its 'Psychology, Culture, and Religion Group' bears a much less straightforward title. Mainstream psychologists of religion typically gather at the American Psychological Association (APA, division 36: Psychology of Religion), the International Society for the Psychology of Religion (publishing the Archiv für Religionspsychologie/Archive for the Psychology of Religion), or at the Society for the Scientific Study of Religion (its journal, the JSSR, regularly publishes work in this field). Undergraduate or graduate programs and chairs in the psychology of religion have been scarce (Wulff 2010: 734) both within psychology and religious studies departments. Courses on religion are not part of the mainstream psychology programs. Accordingly, there is no real market for psychology of religion textbooks: publishers - otherwise eager to publish textbooks - have apparently not pushed for the production of psychology of religion volumes, in sharp contrast to the anthropology and sociology of religion, for which all major publishers have their respective introductory volumes. The same observation imposes itself with regard to handbooks. At the time of writing, there are only three major multi-author handbooks available in print (but an official APA handbook in two volumes is to appear soon): one edited volume (Paloutzian and Park 2005) ${ }^{3}$ and

estrangement many scholars of religion $\backslash$ s have towards these projects. Of course, there are also many psychologists of religion who do not endorse evolutionary psychology.

${ }^{3}$ David Wulff informs me (25 July 2012) that a revised edition will be published soon. 
one co-authored volume, which has moved through four editions since first published in 1985 (Hood, Hill and Spilka 2009); both volumes have a heavy emphasis on empirical methods and both are published by the Guilford Press, ${ }^{4}$ a New-Yorkbased independent publisher with a strong list in psychology and psychiatry, but with no exposure to the study of religion $\backslash s .^{5}$ In addition, there is a single-authored handbook (or over-sized textbook) by David Wulff (b. 1940) that casts its net considerably wider; ${ }^{6}$ by addressing main theoretical and methodological approaches as well as by also reviewing the works and religious views of figures such as Erikson, Freud, Jung, and Winnicott, who are well known among scholars of religion $\backslash \mathrm{s}$ but whose work is hardly mentioned in the handbooks mentioned earlier, Wulff's book shares more ground with the study of religion \s (Wulff 1997; first edition 1991; publisher: John Wiley). In this essay, the focus will lie on introductory textbooks rather than more-encompassing handbooks (but the lines of demarcation are in some cases somewhat fluid).

Given the different trajectories taken by the psychology of religion and the study of religion $\backslash s$ during the past decades, one key challenge for textbooks is the diversity among potential readers. In the following, the focus will not be an assessment of the quality of introductory psychology of religion textbooks in terms of psychology but in terms of the study of religion $\backslash$; ; in other words: are there textbooks that could seem appropriate for adoption in study of religion $\backslash$ s courses? Suppose a study of religion $\backslash \mathrm{s}$ department would be offering an introductory course in psychology of religion: which textbooks are there to choose from, which of these could potentially suit a study of religion $\backslash$ s program and which of these could without greater hurdles be read by students of religion \s who have not taken any preparatory courses in general psychology? Moreover, given that faculty in the study of religion $\backslash \mathrm{s}$ are generally not familiar with current research in psychology, textbooks could or indeed should help build bridges so that faculty can update itself on the current shape of this sub-discipline. When reviewing the available literature, where I will also comment on the didactic arrangement of the material in terms of style and tools meant to enhance the ease of learning, ${ }^{7}$ one soon finds another factor to take into consideration: among the books that do not primarily address psychology students there are some that are meant to appeal to scholars and students of theology or to religious discourses rather than addressing a study of religion $\backslash \mathrm{s}$ audience.

\footnotetext{
${ }^{4}$ The first edition of The Psychology of Religion was published by Prentice-Hall. At that time, Richard Gorsuch was one of the co-authors. The late Bruce Hunsberger joined the editorial team in the second and third editions (replaced by Peter Hill in the fourth edition).

${ }^{5}$ The recent Oxford Handbook of Psychology and Spirituality (Miller 2012) is explicitly framed by a pro-spiritual ('religionistic') agenda as stated by the editor (a professor of psychology and education at Teachers College, Columbia University) in her introductory essay: 'In this handbook, spirituality is understood as ontologically real. Psyche connects us with the greater spirit... This formulation of psyche ... expands psychology by a Copernican magnitude. ... In this handbook, we define an emerging field within a spiritual framework, that of postmaterialism ...' (Miller 2012: 1). The handbook also has a clinical orientation.

${ }^{6}$ Johnston (1998: 275): This work is 'the closest thing to a German-style HANDBOOK that North Americans are likely to see' (in religious studies literature, not only in the psychology of religion). He also refers to Wulff's book as a handbook 'Disguised as a TEXTBOOK' (Johnston 1998: 275).

${ }^{7}$ Of course, the different classroom contexts (including the abilities of the teachers) are eventually decisive for the didactical efficacy of the course and the textbook is only one factor.
} 


\section{An earlier trilogy of textbooks}

Writing in early 2012, at least for the Anglosphere there is a certain sense of deterioration compared to the situation a decade or so ago. Around 2000, in fact, at least three solid introductory textbooks were available in English that have by now gone out of print and not been updated into new editions: An Invitation to the Psychology of Religion by Raymond Paloutzian (1996; first edition 1983); Psychology and Religion: an Introduction by Michael Argyle (2000) and The Psychology of Religion: a Short Introduction by Kate M. Loewenthal (2000).

With 182 pages, Loewenthal's is the shortest of the three and the one requiring least technical knowledge. Loewenthal (now emerita professor of psychology at Royal Holloway, the University of London, who also worked part-time at King's College, London) tries to use simple language; she inserts significant quotations, cases and examples, but does not offer discussion points, further reading, or illustrations. Chapters on the relationships between psychology and religion and psychological themes in religions are followed by chapters on religious behavior (prayer, language, groups and norms, conversion, and exiting groups), religious thoughts (belief and its development across the lifespan, faith and its development), religious feelings (positive and negative feelings, psychopathology) and 'how religion can affect behaviour, thought and feeling' (moral control, stress/distress, prejudice, identity). Interestingly, the book does not cover the topic of religious experience. A strength of Loewenthal's book from a study of religion $\backslash \mathrm{s}$ perspective is her attempt, reflecting her work on culture-sensitive psychology, to break up the implicit identification of religion with Christianity characteristic of much work in the field; Loewenthal makes attempts to address Buddhism, Hinduism, Judaism, New Religious Movements, and some other religions in the text. ${ }^{8}$

Michael Argyle (1925-2002) was one of the best-known English social psychologists of his time. Argyle (who worked at the University of Oxford) is the author of some 44 books on a variety of topics (bodily communication, class, everyday life, happiness, leisure, mental health, money, work, etc.) from a social psychology perspective. In 1958, Argyle published a textbook entitled Religious Behaviour (Argyle 1958; revised 1998, 2000, 2010); revised editions of this work were co-authored with an Israeli psychologist under the title The Social Psychology of Religion (Argyle and Beit-Hallahmi 1975; 1997 with Beit-Hallahmi listed as first author and the revised title The Psychology of Religious Behaviour, Belief and Experience). As the title says, this book explicitly applies a social psychology perspective to religion. At the end of this work Argyle and Beit-Hallahami emphasize the distinctive qualities of aesthetic and religious experiences and they set out a kind of sui generis view of religion: '... religion ... creates a special quality of experience which is not immediately reducible to psychological terms' (Argyle and Beit-Hallahmi 1975: 207). In the preface to his more recent introductory textbook, which emphasizes that 'religion is a social phenomenon' (Argyle 2000: 244), Argyle claims that his is 'a rather unusual book on the psychology of religion' since he takes 'a sympathetic view of religion - I have faith in both enterprises, psychology and religion, and believe that in the end they can be harmonized.' Argyle expresses his hope that the book 'will be of value ... also to those taking courses in religious studies,' for which

${ }^{8}$ Loewenthal is affiliated with Orthodox Judaism. See Loewenthal (2012) for a scholarly autobiography. 
he seems to have theologians in mind since the book ends with some implications for theology (Argyle 2000: 249). To my eyes, the main value of these 285 pages is the author's admirable ability to present concise and readable summaries of a large corpus of empirical studies. His book also provides an outline of Freud's and Jung's views of religion (but he writes less than his peers about conversion). The book has several tables and figures and provides concise summaries, but offers relatively little methodological and conceptual reflection. Argyle's professed sympathetic view of religion comes to the fore in his very explicit portrayal of the 'benefits' of religion, while potential 'costs' are mentioned as an aside, with the additional qualification 'that these may not be experienced as costs' (Argyle 2000: 154) by believers. In the 'Conclusions,' potential negative effects of religion are linked to non-mainstream religious groups such as fundamentalists, strict churches, 'sects and cults,' and charismatic and Pentecostal churches (Argyle 2000: 247-249). The 'many positive effects of religion, some of them strong' (Argyle 2000: 244) are presented as verified psychological knowledge and as explicable by psychology.

An Invitation to the Psychology of Religion by Raymond Paloutzian (b. 1945), the editor of the International Journal for the Psychology of Religion (1991-present) and professor emeritus of psychology at Westmont College (Santa Barbara, California), is not only the longest (304 pages) but also the most advanced of the three older textbooks. The book's 'invitation' is extended to fellow seasoned psychologists, giving it a state-of-the art edge that makes it rather challenging reading for study of religion $\backslash s$ undergraduates. Paloutzian does not hesitate to address methodological and theoretical problems and the first part of the book discusses basic matters of definition, the history of the field, and issues in the philosophy of science. Compared to Argyle's assertive style, Paloutzian seems much more careful in the assessment of research results: 'Few hard conclusions are permissible at this stage of the history of the psychology of religion' (Paloutzian 1996: 264). Paloutzian's book is less concerned with social psychology, but leans somewhat more towards personality psychology. One of its main themes is the multidimensionality of religion as a psychological variable. The book is commendable in didactic terms: besides several tables, figures and pictures, all chapters are supplied with 'Projects and Questions' for further student engagement and selected but not annotated 'Further Reading.'

\section{Textbooks in English currently (2012) in print}

The selection of textbooks in English currently in print is relatively meager. Still in print is a volume first published in 2003 by Blackwell Publishing and the British Psychological Society, a representative body for psychology and psychologists in the U.K. The author, David Fontana (1934-2010), a chartered psychologist and a chartered counseling psychologist with several academic affiliations, was a fellow of the British Psychological Society (which is a high distinction). Fontana also served as a president of the Society for Psychic Research, a U.K. organization seeking to conduct research 'into human experiences that challenge contemporary scientific models' (www.spr.ac.uk/main), also known as parapsychology. Fontana is the author of some 45 books, several of which were translated into other languages; many of these books are not technically academic but popular guidebooks. Social skills, stress management, education and teaching, symbolism, and meditation were among his favorite topics. 
The title of this textbook, namely Psychology, Religion, and Spirituality (Fontana 2003), reflects the growing acceptance of spirituality as a key-term in a field that is in the course of re-labeling itself as the psychology of religion and spirituality (see Hood, Hill and Spilka 2009: chapter 2; Paloutzian and Park 2005; see also below). Even more than Loewenthal, Fontana's textbook seeks to extend his sample of religions beyond (modern Western) Christianity; in particular, he is keen also to include examples from Eastern religions such as Hinduism and Buddhism. Like Argyle, Fontana openly professes 'a position of sympathy toward religion' (Fontana 2003: viii) and like Argyle he highlights the benefits of religion: 'The evidence in the foregoing chapters also shows that religious belief and spiritual experiences appear to enhance well-being and positive relationships, and generally assist in the development of psychological health' (Fontana 2003: 228). But Fontana also acknowledges a 'negative side,' namely that 'religion, by becoming linked to political movements, has frequently been used to authorise or excuse acts of conquest and barbarity' (p. 229). However, Fontana is quick to exonerate religion by adding 'that none of these activities finds any real justification in the teachings of the founders of the great traditions' so that these factors 'arise more from other areas of human ... psychology than from religious or spiritual inclinations per se' (p. 229). Compared to Argyle, Fontana is less optimistic about the achievements of psychology of religion in so far as religion remains 'among the greatest mysteries facing psychology' (p. 228).

In didactic terms, this book of 260 pages has not much to offer. There are some tables, but no pictures, figures, summaries, questions, or further reading. Nowhere is the organization of the volume explained (nor is it immediately apparent from the table of contents) and the different chapters are quite uneven in length: some are only five to ten pages, while two chapters (on 'varieties of religious and spiritual experiences,' covering topics such as mysticism, conversion, personality, and dreams, and on 'concepts of self, soul, and brain' respectively) have almost 50 pages each. The work is not pure mainstream psychology, but leans towards transpersonal psychology and a 'spiritual' commitment; on the one hand, this makes the book independent and partly original, but on the other hand it does not stand out as a representative treatment of mainstream work in the psychology of religion. Authors like Idris Shah and Daisetsu Suzuki are treated as evidence and many of Fontana's arguments engage a kind of comparison that most scholars of religion $\backslash \mathrm{s}$ would no longer consider valid after the post-phenomenological turn in the discipline. Many empirical-minded scholars of religion \s would probably find some of the interpretations of religious traditions and their treatment somewhat questionable or naïve.

Another book that is (still) in print, now in its fourth edition, is Andrew R. Fuller's Psychology and Religion published by Rowman \& Littlefield. The first edition goes back to 1977; over its four editions it has grown from 130 (1977) and 272 (1986) to 302 (1994) and 368 (2008) pages. The first three editions carried the sub-title 'eight points of view' - an appropriate choice since the book basically provides extended summaries of the theoretical positions of eight prominent psychologists, namely James, Freud, Jung, Allport, Maslow, Watts, Fromm, and Frankl, each dealt with in separate chapters (each of 20-40 pages in the 2008 edition). The fourth edition has the subtitle 'classical theorists and contemporary developments.' This reflects the addition of four chapters (amounting to some 100 pages), namely one dealing with a series of further theoreticians in the tradition delineated in the first eight chapters (Winnicott, Pruyser, Rizzuto, Vergote, 
Spilka, Batson, and Grof), ${ }^{9}$ one presenting feminist approaches (with portrayals of the work of Daly, Franzman, Gilligan, and Goldenberg), one about neuroscience (summarizing the work of several scholars, most notably Sperry, Varela, Lutz/ Thompson, Wallace, and Austin), and one on evolutionary theorists (Boyer and Dennett). There is neither a concluding nor an introductory chapter, but a preface in which Fuller, who is professor (now emeritus) of psychology at the College of Staten Island (a college within the City University of New York system), advocates a vision of theoretical diversity and pluralism: 'Religion is many things - there are many ways to be religious. Therefore, many psychologies of religion are necessary' (Fuller 2008: xii). Many scholars of religion \s would agree with such a call to respect the diversity and complexity of our subject matter.

As already indicated, Fuller's book reads like a series of extended summaries of theoretical approaches in the psychology of religion. As such, in a study of religion \s context it could supplement a work like Daniel Pals' Eight (formerly: Seven) Theories of Religion (which also covers Freud), but the book provides only very limited insight into psychology as a field of empirical inquiry, its specific research methodologies, the main topics of discussion, and its different branches. While the selection of authors can be helpful since many of them have produced theories that were productively received in modern religious discourses, the analytical tradition seems somewhat over-represented. In the first eight chapters but only occasionally in the later ones, the more or less extended summaries of the various theories are followed by very brief evaluations - more critical for Freud and Jung, more endorsing for James, Allport, and Maslow - but without any in-depth discussions. Secondary literature is engaged only occasionally, and the book has neither further reading sections nor any other didactic features.

As mentioned above, the term spirituality is increasingly used by psychologists in academic publications. In 2011, a volume bearing the title The Psychology of Spirituality: an Introduction was published by Jessica Kingsley Publishers, independent publishers headquartered in London. Its list focuses on autism, social work, education, and therapies, and it also features spirituality as a separate category in its catalogue. The author, Larry Culliford (b. 1950) is a British consulting psychiatrist who also wrote self-improvement books (under the pen-name Patrick Whiteside); since retiring from the National Health Service in 2007, Culliford devotes his time to writing and research. He is not a professor, but comes from a praxis background, as a member of the Royal College of Psychiatrists, the main professional organization of psychiatrists in the U.K. In 1999 he co-founded its Spirituality and Psychiatry Special Interest Group. In The Psychology of Spirituality he refers to himself as regularly attending Anglican services and as "an ecumenical or "universalist" Christian' (Culliford 2011: 15). The book aims at providing a 'satisfactory and accessible overview of healthy human psychology incorporating the spiritual dimension... designed to be read principally by health and social care professionals and students, and people from related disciplines, including healthcare chaplains' (Culliford 2011: 13). The book of 256 pages is not an introduction to the psychology of religion; it does not review empirical research and only takes a rather cursory glance at some relevant theories, but it is a work with a mission: 'My aim is ... to shed light on mystery and

\footnotetext{
${ }^{9}$ This chapter was already in the third edition, but was revised in the fourth edition.
} 
promote harmony' (Culliford 2011: 16); the author is convinced that 'all will be better off' if 'as many people as possible ... learn how to enquire into their spiritual nature and discover their true selves' (Culliford 2011: 31). The book is a spiritual one that invites people on a gnostic quest to discover their 'true selves' beyond their 'everyday egos.' For Culliford, spirituality 'is not a mere object of analysis or specimen for dissection and scrutiny,' but 'a kind of adventure playground' (Culliford 2011: 34); it 'is about wholeness' (Culliford 2011: 19). Spirituality is 'the "active ingredient" of religion' (Culliford 2011: 39) but can also be found and realized beyond religion. The book is divided into three parts: the first presents the theme of spirituality and its alleged emergent importance; the second follows the development of individual spirituality through Fowler's six stages of development of faith (Fowler 1981); and the short third part recommends a series of spiritual skills and practices. The book offers various autobiographical recollections and the second part seeks to fit a number of biographical narratives, including one of Barrack Obama (who is placed on stage four!) among others, into the stages-model. Chapters are concluded by summary points and exercises and questions aiming at developing readers' own spiritual awareness. In sum, this book serves as a good example of contemporary spirituality discourse and as such is more an object of study than a teaching resource in study of religion $\backslash \mathrm{s}$ contexts.

To conclude, the selection of psychology of religion textbooks currently available in English turns out to be severely limited in its potential appeal for study of religion \s programs. Do other languages fare better?

\section{An Italian textbook}

As far as I can see, no introductory textbooks are currently available in Spanish and French. ${ }^{10}$ In Italian, however, a sort of introductory book was published in 2008. The author, Eugenio Fizzotti (b. 1946), a Catholic priest belonging to the Salesians of Don Bosco, has been a professor of psychology of religion and 'professional deontology' as well as dean of the Faculty of Education at the Salesian Ponteficial University in Rome. Before studying theology, Fizzotti took a degree in psychology and studied for one year, in 1969-70, with Viktor Frankl in Vienna. In addition to his ongoing work on Frankl's psychology, Fizzotti has also published quite extensively on New Religious Movements (NRMs). In fact, the last three of the seven chapters of this textbook of 165 pages deal with NRMs, the 'care for the self' in contemporary religion, and the New Age movement. These chapters are as much theological as they are psychological and the discussions are full of religious language and value judgments. Yet the first chapter defines the psychology of religion as an empirical discipline and commits itself to 'methodological exclusion of the transcendent' (Fizzotti 2008: 19 ) in the spirit of sympathy. Instead of psychology of religion, Fizzotti prefers to speak of the 'psychology of religious attitudes' (p. 26). The second and

\footnotetext{
${ }^{10}$ The closest one comes is Roussiau (2008), an edited volume that introduces topics such as socialization, conversion, discrimination, cognitive bias, aging, and some others from the point of view of social psychology. Earlier key publications in French are Vergote (1966) (Italian translation 1968; German translation 1970) and Godin (1981) (English translation 1985); the latter concludes on an explicitly Christian note.
} 
longest chapter reviews main theoretical approaches in the study of religious attitudes (Freud, Adler, Jung, James, Fromm, Allport, Maslow, Frankl, and the Italian theosophist and humanistic and transpersonal psychologist Roberto Assagioli). Chapter three discusses religion as a field of psychological research with an emphasis on the different dimensions of religion. The fourth chapter deals with the processes of arriving at 'religious maturity.' It is from this chapter onwards that religious statements become quite dominant (see e.g., Fizzotti 2008: 96, 99, 101-102, etc.). From a study of religion $\backslash \mathrm{s}$ perspective this books appears as an attempt to integrate psychology into a religious project. In didactic terms, the book does not offer any relevant tools.

\section{Textbooks in German}

In German one finds one collaborative, edited volume and several monographs, ${ }^{11}$ mainly written by theologians. Even though the majority of the contributors to the edited volume (Henning, Murken and Nestler 2003) are psychologists, two of its editors are theologians and the book ends with a concluding chapter explicitly framed as a theological perspective, where one learns that the majority of scholars working on the psychology of religion in Germany are, in fact, theologians and that the quality of their work was often not appreciated by professional psychologists (Henning, Murken and Nestler 2003: 236-237). The first 90 pages out of the 260 in the book give an outline of the history of the psychology of religion in German-speaking countries. The second main section comprises essays that give up-to date overviews of three main topics of empirical research: conversion (Ulrike Popp-Baier); religious development (Elfriede Billmann-Mahecha); and religion and (mental) health (Marion Schowalter and Sebastian Murken). The third main section discusses research methods in psychology and religion, divided into two groups: quantitative (Uwe Wolfradt and Gisela Müller-Plath) and qualitative (Ulrike Popp-Baier). All chapters seem solid, but the organization of the volume raises doubts about the utility of the volume as an introductory textbook. To begin with, which audience without any previous knowledge would benefit from a detailed presentation of the history of the field in Germany amounting to a third of the entire volume - and who would find that engaging? The chapters on key issues or themes are too few and too condensed to serve as the basis for a course, and they are not supplied with any didactic tools. Finally, the methodological chapters, while very helpful in their own rights, could have been more usefully integrated into the volume, especially in conjunction with the chapters on key issues. A useful feature of the volume is an appendix containing an annotated bibliography of relevant publications.

The textbook by Susanne Heine (b. 1942), a practical (Protestant) theologian teaching in Vienna, also devotes a large number of pages to history and methodology (Heine 2005). Lengthwise (442 pages) Heine's work is a handbook more than an introductory textbook. The second chapter of her work reviews the early history of psychology and competing positions in the early history of the psychology of religion. (To my eyes, this discussion is too detailed and too remote to

\footnotetext{
${ }^{11}$ An earlier introductory overview in German is Mann (1973). On the Protestant theologian and religion scholar Ulrich Mann see Tworuschka (2011: 268-284).
} 
engage beginners.) The third chapter discusses methodology. Compared to the chapters in Henning, Murken and Nestler (2003), Heine's discussion is less practical but she lays her hands on more basic issues in the philosophy of science and epistemology. She is highly critical of scientism, i.e., models adapted from the natural sciences, and quantitative methodologies. For these reasons, probably, the bulk of empirical research in contemporary psychology of religion is neither presented nor discussed in Heine's book. From the fourth chapter onwards (starting with page 107 !), the book moves on its main track, namely a series of chapters on leading 20th-century psychologists of religion. Heine devotes one chapter each to the trinity of James, Freud, and Jung, while other chapters present the work of some more or less similar-minded scholars (post-Freudians: Winnicott, Pruyser, Rizzuto; Becker and Terror Management Theory, Vergote, Sundén; humanistic psychology: Maslow, Rogers, Perls; Goldstein, Allport, Frankl). The book ends with a very short concluding chapter, in which Heine praises the psychology of religion as an excellent example for interdisciplinarity (Heine 2005: 396). Compared to the book by Andrew Fuller, who also reviews the work of main psychologists of religion, Heine's presentation is not longer, but more advanced. By focusing on the theorists' views of religion and their anthropological views, Heine's examination has a clear focus and she takes secondary literature into account and discusses the reception of their work. Unfortunately, there are no didactic tools such as further reading sections, keywords, or discussion questions. By working through Heine's book, readers get a good idea of main psychological theorists, but what do they learn about the psychology of religion as a field of research? Similarly, few scholars of religion \s would think, I assume, that readers of Pals' book (2006) or others of that kind (Kunin 2003; Strenski 2006) get a sufficient idea of the nature of the study of religion $\backslash \mathrm{s}$.

One year after Heine, another Protestant theologian, Godwin Lämmermann (b. 1947), who teaches religious pedagogy and didactics of religious education at Augsburg University (Germany), published a book explicitly labeled as an 'introduction to the psychology of religion' (Lämmermann 2006). With its 405 pages, however, it is a rather long introductory textbook. The book has ten chapters, which can be subdivided into three main sections: two introductory chapters (on the psychology of religion in general), three chapters that review three main approaches to the psychology of religion (which he labels experimental-empirical-behavioristic psychology, depth psychology, and cognitive-structuralism) and five chapters dealing with areas of research in the psychology of religion, namely health, personality, death, prejudice (in particular anti-Semitism), and 'superstition and postmodern religiosity.' Lämmermann is not primarily interested in engaging the most recent literature on any of these subjects; few of the items in his bibliography were published in 2000 or later and among those that do appear, only a minority deals with psychology in a stricter sense. In general, Lämmermann has reservations towards mainstream psychology because of its basic epistemological limitations. His own vision of the field, however, remains somewhat vague (at least to this reader), partly because his key notion of a 'deep hermeneutical' approach (which he endorses) is often invoked but never spelled out systematically; it seems to be akin to depth psychology, but the exact differences remain unclear; it aims at a kind of 'hermeneutics of suspicion' that finds itself in a position to go beyond that which is said to 'other' or deeper meanings. In general, Lämmermann's style is not very concise 
and the arguments are not always well structured. Accordingly, the book does not offer any summaries or other didactic tools such as definitions of key terms, etc. Lämmermann's agenda is 'critical,' which also allows him to challenge the 'fetishism of method' (Lämmermann 2006: 29). Given the biographical imprint of the researchers, a general psychology of religion is not possible; it should rather be narrowed down to a psychology of Christianity (Lämmermann 2006: 61). The chapter on 'superstition and postmodern religiosity' is mainly a critique phrased in depth-psychological terminology or even amounts to outright polemics. His problems with recent developments in religion also find expression in his dismissal of the category spirituality (Lämmermann 2006: 42). Several interesting reflections notwithstanding, I would not recommend using Lämmermann's work as a textbook.

In contrast to the other German books, the volume by Bernhard Grom (b. 1936) ${ }^{12}$ has run through several editions since its first appearance in 1992 (second edition 1996; third, substantially revised version 2007). ${ }^{13}$ The author, a Jesuit, taught psychology and pedagogy of religion at the Munich School of Philosophy (Hochschule für Philosophie), a college run by the Jesuits. In the introduction to his 330-page third edition, Grom expresses his commitment to mainstream scholarly work in the field; he emphasizes the neutrality of the discipline, warns against crossing the boundaries to apologetics and polemics, and stresses that the psychology of religion should avoid radical reductionism. Yet Grom regards the psychology of religion as an engaged science committed to psychic wellbeing and favorable conditions of personality development (Grom 2007: 14). He wishes to coherently describe and explain the complexity and diversity of religiosity and subscribes to a 'coherent eclecticism' in theoretical and methodological terms; he wants to have it both ways by seeking to achieve both pluralism and an integrated perspective. The book is divided into two main parts: religiosity as part of personality and religiosity in the context of social influences. The second part (Grom 2007: 261-289) is much shorter than the first and also less persuasive. It is made up of two short chapters, one on learning (where Grom does not provide any examples) and one on membership in new religious movements (which he refers to as 'spiritual groups') in the tension between resource and danger, which ends by giving some advice on how to support persons who are likely to leave 'extreme or problematic groups' (Grom 2007: 288). Even though Grom tries not to write deprecatingly and emphasizes the heterogeneous structure of this field, he appears to be more concerned with potential damage done than with giving a rounder picture of the diversity of the field. The first part of the book is made up of four chapters. The first and longest chapter is central to its theoretical agenda: in it, Grom tries to elucidate the intrinsic motives for religiosity. He begins with a very concise review of six major theoretical approaches (Pawlow; Malinowski and Terror Management Theory; Freud; object-relations theory; attachment theory; attribution theory; Allport) before outlining his own (somewhat arbitrary) theory of six major intrinsic motives or dispositions (moral self-control; control of life events and coping; positive sense of selfesteem; gratitude and veneration; pro-sociality; intellectual coherence). His

\footnotetext{
${ }^{12}$ See Grom (2012) for an autobiographical account.

${ }^{13}$ The book is translated into Spanish and Polish.
} 
emphasis on motives is supplemented by a focus on emotions and states of consciousness. Other sub-chapters deal with god-concepts, religious development, and subjective wellbeing. The main strength of the volume is its didactic approach. Grom's style is concise, clear, and critical; he avoids technical jargon. His discussions are often framed as questions so that the main agenda of the topics obtain a clear focus and relevance. Moreover, Grom provides numerous didactic tools such as tables, figures, and lists of bullet points. Especially valuable as illustrations of the discussion are some 34 brief examples of individual cases and almost as many passages where Grom provides quotations from religious writings, explains the background of religious conflicts, or introduces some additional points of view. On the margins of almost each printed page one take-home point is displayed. Most of his materials remain within the orbit of Western religious history.

Also in German-speaking academia, spirituality has emerged as a guiding concept and the psychology of religion is sometimes re-launched as the psychology of spirituality. In 2007, Anton A. Bucher (b. 1960), who teaches practical theology at the University of Salzburg (Austria), published a textbook on the psychology of spirituality (Bucher 2007). This book of 228 pages summarizes a large bibliography (not only of publications on spirituality but also on religion). Admittedly, the author draws on both empirical and speculative works. He is sympathetic to the spiritual agenda and reluctantly engages evolutionary and genetic theorizing on the origins and adaptive functions of spirituality. Bucher draws on transpersonal psychology and criticizes the 'objectivist paradigm' and traditional research methods. At the same time he is often keen to present to his readers the 'hard facts' established by scientific research. Given that most studies were conducted in the U.S., Bucher sometimes raises the question of the validity of their results for the situation in Germany. His discussion often refers to critical views and he is not always forthright about his own. The discussion is illustrated by a series of very brief individual cases. The main chapters of this book review research on the definition and measurement strategies (scales) of spirituality, the development of spirituality across the lifespan, negative and positive effects of spirituality on physical and mental health, and spirituality in psychotherapy. Bucher advocates a view of spirituality that mainly sees it as a kind of connectivity and relationship to an ultimate, spiritual, holy reality (Bucher 2007: 56). Bucher's final chapter on potential uses of spirituality or spiritual practice in psychotherapy (which he seems to endorse) laments the lack of relevant research done on this issue in Europe. Even though Bucher is a theologian, psychologists are the intended audience of the book and its main agenda is the review of the state of the art of results in research on spirituality. Accordingly, it does not offer any didactic tools tuned to a student audience.

\section{A Swedish example}

In contrast to Germany and Austria, where there are no chairs in the psychology of religion, Sweden currently has two such chairs, both placed within schools of theology at the country's two oldest universities (Uppsala and Lund). The two scholars who hold the respective chairs, Owe Wikström (b. 1945; Uppsala) and Antoon Geels (b. 1946; Lund), published in 1985 a co-authored introductory textbook that in the meantime has gone through several revised editions $(1989 ; 1993 ; 1999$; 
2000; 2006). ${ }^{14}$ This book of 465 pages (2006) is widely used as a textbook in Scandinavian universities; it is didactically devised as such by being written in an accessible style and by providing several cases and examples, clear bullet-point summaries of the chapters, annotated further reading lists and additional bibliographies. In their introduction, which seeks to delimit the field, the authors state that the psychology of religion is based on data, methods, and theories from general psychology; but they also argue that doing research in this field requires solid training in both psychology and the study of religion $\backslash \mathrm{s}$, and that it is in the encounter between these two fields that new knowledge is being stimulated and produced (Geels and Wikström 2006: 27). The book is divided into two main parts, one with a focus on theories and one with a focus on topics such as religious visions, mysticism, personality psychology, clinical psychology of religion and pastoral care, coping, and contemporary spirituality (including NRMs, fundamentalist movements, and suicide terrorism). The first, theoretical, part is divided into three chapters where the authors lay out theoretical perspectives, which, in the first chapter, are mainly inspired by social constructivism and the sociology of knowledge; in particular they draw on Berger/Luckmann. These perspectives are complemented in Chapter two by role theory (Sundén), cultural psychology of religion (Belzen), and attribution theory. Several sub-chapters seek to apply the theoretical approaches to case studies. The third chapter reviews psychoanalytical perspectives (mainly limited to Freud and Jung). Additional gender perspectives are offered throughout the theoretical part. In line with the Swedish research tradition in psychology, which in this country has grown out of the history of religions (until the 1960s scholars of religion in Uppsala had a double venia legendi in history and psychology of religion), the authors pay a great deal of attention to historical materials and they provide several examples from church history, Islam, Hinduism, and Buddhism. ${ }^{15}$

\section{Prospects}

If scholars in the study of religion $\backslash$ s agree on anything, it is on the complexity and diversity of the subject matter ('religion $\backslash s^{\prime}$ ). Sensing the dangers of essentialism or reification, scholars have become increasingly reluctant to attribute anything to 'religion,' and for many scholars of religion, attempts by psychologists to say anything about religion in general may appear like a gross simplification. At the same time, research in mainstream psychology of religion gives further impetus to this

\footnotetext{
${ }^{14}$ At the time of writing (Spring 2012), a new edition is being announced. The later editions (from 1999 onwards) include additional chapters by two or three younger colleagues. Earlier textbooks include Sundén (1974) (revised editions 1977; 1981; German translation 1982); Holm (1985) (revised editions 1988; 1993; 2002; German translation 1990 and several subsequent editions; English translation 1987 under the title Scandinavian Psychology of Religion; German translation 1990. Since the book was published by a small Finnish publisher it seems to have had very limited impact in the Anglosphere). Hjalmar Sundén (1908-93) is generally acknowledged as one of the founders of the modern psychology of religion (see Sundén 2012 for autobiographical recollections); his major contribution was his role theory; Nils G. Holm (b. 1943) is a student of Sundén, who developed his theories further; until his retirement, Holm was professor of religion at the Swedish speaking Åbo Akademi in Åbo/Turku in Finland. ${ }^{15}$ See also the programmatic statement by Sundén (2012: 241): 'Thus anybody who seeks to practice the psychology of religion must first acquire a sound knowledge of the history of religions; this is really the first requisite.'
} 
tendency and substantiates it by adding differentiations that are often ignored by religion scholars: religiosity varies across individuals in relation to their personalities, socialization, learning styles, development, life situations, cognitive and emotional processes, etc. Moreover, psychology has produced many theories and theoretical models seeking to explain (different aspects of) religion or religiosity. For these reasons, the study of religion $\backslash$ s seems well advised to attend to developments in this field and to integrate relevant knowledge in study of religion $\backslash$ s programs. Unfortunately, with the possible exception of the books by Geels/Wikström and (to a lesser degree) Grom, the available textbooks only to a very limited degree allow for this to happen.

Someday, a scholar of religion $\backslash \mathrm{s}$ and a psychologist (of religion) should get together and try to work toward an integrated textbook that allows readers from both fields to mutually recognize their subject matter when writing about the psychology of religion; this would certainly be a challenging, but perhaps also a rewarding task. From my perspective, such a work, in order to be used in study of religion $\backslash$ s programs, would need to live up at least to the following expectations (in addition to fulfilling the requirements of textbooks as a genre such as clear style and structure, chapter summaries, etc.):

(1) It should not be governed by either a pro- or an anti-religious agenda, nor should it be polemical towards some forms of religion;

(2) It should present religion not only as a Western (American) and modern phenomenon;

(3) It should avoid a naïve concept of religion and critically discuss strategies to operationalize this concept and other relevant concepts in relation to literature used in both disciplines (where the divergence between the two discursive traditions should be commented on);

(4) It should seek to introduce main theories and empirical work in the psychology of religion, covering key issues in mainstream work in the psychology of religion such as conversion and religious development across the lifespan and constructively relating these to debates within the study of religion $\backslash \mathrm{s}$;

(5) It should include a variety of research questions to reflect the breadth of psychology as an academic mega-discipline;

(6) It should critically discuss the research methodologies and metatheoretical implications and assumptions governing empirical work in the psychology of religion;

(7) It should provide some brief exemplary case studies, preferably from different cultural contexts, to illustrate procedure and relevance of work in the psychology of religion.

\section{Acknowledgments}

Thanks to David Wulff, Sebastian Murken, Nils G. Holm, Knut Melvær, Alexander Rödel, and Håkon Tandberg for comments on earlier drafts of this essay.

Michael Stausberg is Professor of Religion at the University of Bergen and a member of the Norwegian Academy of Science and Letters. 


\section{References}

Antes, Peter, Armin W. Geertz, Randi R. Warne, eds. 2004. New Approaches to the Study of Religion. Vol. 2 vols. Berlin, New York: Walter de Gruyter.

Argyle, Michael. 1958. Religious Behaviour. London: Routledge \& Kegan Paul.

Argyle, Michael. 2000. Psychology and Religion. An Introduction. London, New York: Routledge.

Argyle, Michael, Benjamin Beit-Hallahmi. 1975. The Social Psychology of Religion. London, Boston: Routledge \& K. Paul.

Belzen, J.A. 2005. Methodological Concerns in the Psychology of Religion: Continuities, Losses and Transforming Perspectives. Religion 35/3: 137-165. DOI 10.1016/j.religion.2005.07.001.

Bucher, Anton A. 2007. Psychologie der Spiritualität: Handbuch. Weinheim: Beltz PVU.

Connolly, Peter. 1999. Psychological Approaches. In Approaches to the Study of Religion, ed. Peter Connolly. London, New York: Continuum, 135-192.

Culliford, Larry. 2011. The Psychology of Spirituality: An Introduction. London, Philadelphia: Jessica Kingsley Publishers.

Engler, Steven. 2008. Field Guides to the Study of Religion. Religious Studies Review 34/1: 17-29. DOI 10.1111/j.1748-0922.2008.00236.x.

Engler Steven, Michael Stausberg. 2011. Introductory Essay. Crisis and Creativity: Opportunities and Threats in the Global Study of Religion \s. Religion 41/2: 127-143. DOI 10.1080/0048721X.2011.591209.

Fizzotti, Eugenio. 2008. Introduzione alle psicologia della religione. Milano: FrancoAngeli.

Fontana, David. 2003. Psychology, Religion, and Spirituality. Malden, MA: BPS Blackwell.

Fowler, James W. 1981. Stages of Faith: The Psychology of Human Development and the Quest for Meaning. San Francisco: Harper \& Row.

Fuller, Andrew Reid. 2008. Psychology and Religion: Classical Theorists and Contemporary Developments . Four edn. Lanham etc: Rowman \& Littlefield Publishers.

Geels, Antoon, Owe Wikström (with Jan Hermanson and Petra Junus). 2006. Den religiösa människan: en introduktion till religionspsykologin. Stockholm: Natur och kultur.

Godin, André. 1981. Psychologie des expériences religieuses: le désir et la réalité. Paris: Le Centurion.

Grom, Bernhard. 2007. Religionspsychologie. München: Kösel.

Grom, Bernhard. 2012. Toward a Mainstream Psychology of Religion Beyond Poor Relation Status. In Psychology of Religion: Autobiographical Accounts, ed. Jacob A. Belzen. New York: Springer US, 71-90. DOI 10.1007/978-1-4614-1602-9_5.

Heine, Susanne. 2005. Grundlagen der Religionspsychologie: Modelle und Methoden. Göttingen: Vandenhoeck \& Ruprecht.

Henning, Christian, Sebastian Murken, Erich Nestler. 2003. Einführung in die Religionspsychologie. Paderborn: Ferdinand Schöningh.

Holm, Nils G. 1985. Religionspsykologins grunder. Åbo: Åbo Akademi.

Hood, Ralph W., Peter C. Hill, Bernard Spilka. 2009. The Psychology of Religion: An Empirical Approach. New York, London: Guilford Press.

Johnston, William M. 1998. Recent Reference Books in Religion: A Guide for Students, Scholars, Researchers, Buyers $\mathcal{E}$ Readers. Revised edition. Chicago: Fitzroy Dearborn.

Kirkpatrick, Lee A. 2011. The Role of Evolutionary Psychology Within an Interdisciplinary Science of Religion. Religion 41/3: 329-339. DOI 10.1080/0048721x.2011.604511.

Kunin, Seth D. 2003. Religion: The Modern Theories. Baltimore, London: The John Hopkins University Press.

Lämmermann, Godwin. 2006. Einführung in die Religionspsychologie: Grundfragen - Theorien - Themen. Neukirchen-Vluyn: Neukirchener Verlag.

Loewenthal, Kate M. 2000. The Psychology of Religion: A Short Introduction. Oxford: Oneworld.

Loewenthal, Kate Miriam. 2012. Changing Ways of Doing Things: An Autobiographical Account of Some of My Experiences in the Psychology of Religion. In Psychology of Religion: Autobiographical Accounts, ed. Jacob A. Belzen. New York: Springer US, 133-153. DOI 10.1007/978-1-4614-1602-9_8.

Main, Roderick. 2006. Psychology of Religion. In The Blackwell Companion to the Study of Religion, ed. Robert, Alan Segal. Malden: Blackwell, 147-170.

Mann, Ulrich. 1973. Einführung in die Religionspsychologie. Darmstadt: Wissenschaftliche Buchgesellschaft.

Merkur, Dan. 2005. Psychology of Religion. In Routledge Companion to the Study of Religion, ed. John R. Hinnells. London: Routledge, 164-181.

Miller, Lisa J. 2012. The Oxford Handbook of Psychology and Spirituality. New York: Oxford University Press. 
Orsi, Robert A., ed. 2011. The Cambridge Companion to Religious Studies. Cambridge, New York: Cambridge University Press.

Paloutzian, Raymond F. 1996. Invitation to the Psychology of Religion, Second edition. Boston etc: Allyn and Bacon.

Paloutzian, Raymond F., Crystal L. Park, eds. 2005. Handbook of the Psychology of Religion and Spirituality. New York: Guilford Press.

Pals, Daniel L. 2006. Eight Theories of Religion. New York: Oxford University Press.

Roussiau, Nicolas, ed. 2008. Psychologie sociale de la religion. Rennes: Presses Universitaires de Rennes.

Strenski, Ivan. 2006. Thinking about Religion: An Historical Introduction to Theories of Religion. Malden, Oxford, Victoria: Blackwell.

Sundén, Hjalmar. 1974. Religionspsykologi: problem och metoder. Stockholm: Proprius.

Sundén, Daniel Anders Hjalmar. 2012. From the History of Religions to the Psychology of Religion. In Psychology of Religion: Autobiographical Accounts, ed. Jacob A. Belzen. New York: Springer US, 233-242. DOI 10.1007/978-1-4614-1602-9_14.

Tworuschka, Udo. 2011. Religionswissenschaft: Wegbereiter und Klassiker. Cologne, Weimar, Vienna: Böhlau.

Valle, Edênio. 2007. A psicologia da religião. In O espectro disciplinar da Ciência da Religião, ed. Frank Usarski. São Paulo: Paulinas, 121-167.

Vergote, Antoine. 1966. Psychologie religieuse. Psychologie et sciences humaines. Bruxelles: Charles Dessart. Wulff, David M. 1997. Psychology of Religion. Classic and Contemporary, Second edition. New York: Wiley. Wulff, David M. 2010. Psychology of Religion. In Encyclopedia of Psychology and Religion, ed. David A. Leeming, Kathryn Madden and Stanton Marlan. Springer, 732-735. DOI 10.1007/978-0-387-71802$6 \_542$. 